Journal of Spatial Science

\title{
State and development of local spatial data infrastructures in Croatia
}

\section{Slaven Marasović, Joep Crompvoets \& Vesna Poslončec-Petrić}

To cite this article: Slaven Marasović, Joep Crompvoets \& Vesna Poslončec-Petrić (2018): State and development of local spatial data infrastructures in Croatia, Journal of Spatial Science, DOI: 10.1080/14498596.2018.1429331

To link to this article: https://doi.org/10.1080/14498596.2018.1429331

$$
\text { 曲 Published online: } 19 \text { Feb } 2018 .
$$

Submit your article to this journal

Џ Article views: 59

View Crossmark data ¿ 


\title{
State and development of local spatial data infrastructures in Croatia
}

\author{
Slaven Marasovića ${ }^{\text {, Joep Crompvoets }}{ }^{\mathrm{b}}$ (iD) and Vesna Poslončec-Petrićc \\ ${ }^{a}$ Vodoprivredno-projektni biro, d.d., Zagreb, Croatia; ${ }^{b}$ Public Management Institute, Katholieke Universiteit \\ Leuven, Leuven, Belgium; 'S Sveuciliste u Zagrebu Geodetski Fakultet, Zagreb, Croatia
}

\begin{abstract}
This research was carried out as part of a $\mathrm{PhD}$ thesis: local spatial data infrastructure (LSDI) assessment and development model in the Republic of Croatia. Forty-three percent of cities have GIS or LSDI for city management. The percentage of LSDIs in cities in Croatia is rising. In five years, from 2011 to 2016, there were six percent more LSDIs in Croatia. LSDIs in Croatia have problems with many factors related to SDI: organizational, informational, human resources, technological and financial resources. There is a difference between LSDI readiness in smaller and bigger cities. Bigger cities (by budget and by population) are much more ready than small cities for LSDI development and management. Besides the budget and population, the existence of an IT expert in city government has a positive influence on the development and quality of LSDI in cities.
\end{abstract}

\section{KEYWORDS}

LSDI; Croatia; questionnaire; budget; population; IT

\section{Introduction}

The most detailed spatial data can be found at the local level of spatial data infrastructures (SDIs). These data are essential for the establishment of the SDI at all levels, from local to national level (NSDI) and even international level (e.g. INSPIRE). As a member of the European Union (EU), Croatia is obligated to fulfil the requirements of the INSPIRE Directive. All public-sector spatial data should be available and comply with the INSPIRE implementing rules by 2020 , which includes spatial data from the local level as well.

SDIs in the EU differ between countries as the same INSPIRE implementation rules or differences between countries may cause different results. National SDIs cannot be the same, and differ considerably depending on political, administrative, economic and cultural national circumstances (Crompvoets et al. 2008).

The same is more or less valid for local spatial data infrastructures (LSDI). Any framework for the assessment of LSDI is likely to be adapted to the particularities of cities. Also, the objectives of SDI and the relevant indicators of SDI assessment may vary. Also, there are different models for SDI development and they can be divided into three main 'directions' of development: bottom-up, top-down or middle-out. 
The SDI assessment will play a crucial role in managing SDI initiative(s). In this context, identifying critical factors and processes in the acquisition, implementation and utilization of an SDI assessment can make it easier to develop an SDI model in a specific area. As part of this process, SDI coordinating agencies will then be able to better define and develop their strategies to implement it or to achieve their objectives (Rajabifard 2007).

In Croatia several assessments have been related to local SDI initiatives. Cetl (2007) investigated sub-national SDIs at the county level in the Republic of Croatia in order to analyse improvements to the existing SDIs. Poslončec-Petrić (2010) analysed the distribution of spatial data for official cartography in the Republic of Croatia. Blagonić (2012) investigated utility registers over local geoportals in all 127 cities in the Republic of Croatia. Hećimović et al. (2014) investigated Croatian LSDI and analysed it according to the indicators city budget, city population and city area.

This research provides an overview of the status and development of LSDI. Also, the gap between the current state and the state aimed at by INSPIRE for 2020 was assessed. By 2020, the whole set of INSPIRE should be implemented, which includes Annex III data themes which are related to local government. The data theme Utility and governmental services includes data about administrative and social governmental services, common utility network elements, the electricity network, environmental management facilities, the oil-gas-chemical network, the sewer network, the thermal network and the water network.

\section{Local SDls}

Local governments have been recognized as an early leader in the development and application of spatial information systems (McDougall et al. 2005). McDougall et al. (2005) in their research conducted in Australia on LSDI state that the lack of support from other levels of SDI for the development of SDI at the local level is disappointing. Tulloch and Harvey (2007) through case studies examined local government data-sharing practices and state the importance of the existence of political, institutional, technical and legal support on the development of LSDI. In the research on over 100 local governments in Australia, McDougall et al. (2009) state that data-sharing is of great importance for developing SDI from the local level (bottom-up approach).

Lack of initiatives for cooperation (McDougall et al. 2005), or vertical integration of data from the national level to the local SDI, leads to a slower development of SDI at the local level. The disadvantages of such non-cooperation are reflected at the national level, especially through the impossibility of integration of data from the local level into the NSDI (Jacoby et al. 2002). Lack of awareness of national spatial data infrastructures (NSDIs) is recognized through the research within the project 'Potentials and Pitfalls of the NSDI for Local Governments' conducted in the territory of the United States (Harvey and Tulloch 2003). Still, since the spatial data relevant to NSDI are mostly under the care of the local authorities, the role of the local level has been recognized as crucial for the development of a national SDI (McDougall et al. 2002). Local government is a key user and producer of datasets at the local level and is able to play a major role in shaping the entire NSDI and providing feedback on its effectiveness (Jacoby et al. 2002).

The main objective of the establishment of SDI at the local level is to support economic development, better governance and sustainable development (McDougall et al. 2009). The 
problem of small local governments is reduced capacity of investment in the development of such systems. Multiple uses of non-redundant data raise the awareness of the utilization of spatial data for various purposes, which increases the value of spatial data without additional investment (Tulloch and Harvey 2007).

Worldwide, large investments have been made to develop SDI initiatives. Given the expenditure and society's interest in the proper and effective use of these funds, it has become a necessity to have reliable methods and instruments to assess SDI initiatives (Rix et al. 2011). There are many assessment methods for SDI status and development (Crompvoets et al. 2008, Vico et al. 2010, Vandenbroucke et al. 2013). The multi-view framework contains methods that not only evaluate SDI performance but also deepen our knowledge about SDI functioning, and may assist in its development (Grus et al. 2008).

Rix et al. (2011) introduce a new approach to identify, analyse and assess SDI. This approach has been developed by the Thematic Network eSDI-Net+ and has been validated in a comprehensive survey involving about 200 SDIs from 26 European countries as well as different stakeholders involved in the creation and use of SDIs throughout Europe. It provides a pragmatic approach to analyse and evaluate subnational SDIs, considering best practices from which SDI stakeholders can learn (Rix et al. 2011). For example, assessment of LSDIs in 98 municipalities based on the eSDI-Net+ SDI Self-Assessment Framework has been conducted in Denmark (Christiansen et al. 2011).

It is important that developers create and follow a roadmap for implementing an SDI and assess the development and performance of the SDI. Aspects identified in developing an SDI roadmap include the vision, the improvements required in terms of national capacity, the integration of different spatial datasets, the establishment of partnerships as well as the financial support for the SDI. The SDI vision helps people understand the government's objectives and work towards achieving these objectives (Rajabifard 2007). The INSPIRE roadmap shows that the whole of INSPIRE should be operational by 2020 (EEA (European Environment Agency) 2014). So, for Croatia as well, the objective is to fulfil the demands of the INSPIRE Directive, including Annex III, as most related to the local level of SDI.

In Croatia there are 127 cities, 428 municipalities and 20 counties (URL2). The whole area of the Republic of Croatia is covered by cities and municipalities. The heterogeneity in the development of LSDI in Croatia is expected also because the spatial data of some cities were destroyed during the war in the 1990s.

To understand the situation of LSDI in Croatia it is necessary to conduct research with cities. Conclusions about the dynamics of development of LSDI can be reached by comparing results from the research with other research. Additionally, the main obstacles for LSDI development and LSDI management can be recognized. All this can help fill the gap between the current situation and the situation aimed at for 2020 by INSPIRE.

\section{Research objectives}

The aim of this research is to provide an overview of the status and development of local spatial data infrastructures in the Republic of Croatia.

The research will investigate the expectations of the representatives of the cities, the status of LSDI and cities' readiness to develop LSDI and the main obstacles to the development of LSDI in Croatia to fulfil the demands of the INSPIRE Directive. Also, initiatives 
necessary to bridge the gap between the current and future (INSPIRE 2020) LSDI development in Croatia will be defined.

The results of the research were compared with previous research of LSDI in Croatia. The comparison with previous research is done to recognize the direction of the current development of LSDI in the Republic of Croatia.

\section{Research methodology}

Before beginning this current research, a detailed review of the framework for the assessment of LSDI was done. Special attention was paid to the frameworks for assessment that could be the most appropriate for LSDI assessment in Croatia since LSDI in Croatia is not well developed, based on previous research (Hećimović et al. 2014). Frameworks for SDI evaluation that were reviewed in more detail were: the National Spatial Data Infrastructure Readiness model (Delgado Fernandez et al. 2008), the eSDI-Net+ SDI Self-Assessment Framework (Vico et al. 2010), Evaluation and Performance Indicators to Assess Spatial Data Infrastructure Initiatives (Steudler et al. 2008), the Framework for Designing Performance Indicators for Spatial Data Infrastructure Assessment (Giff 2008, Giff and Crompvoets 2008), INSPIRE State of Play: Generic approach to assess the status of NSDIs (Vandenbroucke et al. 2008) and methodology to assess the performance of spatial data infrastructures in the context of work processes (Vandenbroucke et al. 2013).

The purpose of this literature and documentation review is to compare the frameworks for assessment and to adapt them to circumstances in the Republic of Croatia. For this purpose, previously conducted research in the Republic of Croatia related to LSDI was used (Cetl 2007, Poslončec-Petrić 2010, Blagonić 2012, Hećimović et al. 2014). Also, LSDI research from other EU countries was used (Local Government Association - United Kingdom (LGA) 2011, Christiansen et al. 2011).

In the next step, survey questions were prepared. Literature and various research and methodologies (Hećimović et al. 2014, State of Play, eSDI-Net+ and SDI Readiness) were used in devising the questions. Existing literature and documentation about the previously identified problems were examined. Also, the characteristics (level of knowledge, economic situation, governance, etc.) of Croatia and state of (L)SDI in Croatia were taken into consideration. The level of knowledge about SDI and INSPIRE is not so high, so those facts were taken into consideration in the process of designing questions. The final version of this questionnaire emerged from the research preparation process as shown on Figure 1.

The size of the sample in this research is clearly defined by the number of cities (127) in the Republic of Croatia (URL1). Prior to the survey, an invitation was sent to city representatives. The invitation was sent to the department for LSDI. If there was no such department, the invitation was sent in the following order to departments for physical planning, construction, protection of the environment or utility cadastre. In the research, the first communication with cities and the first invitation to the questionnaire came from the Association of Cities of the Republic of Croatia. The invitation contained an explanation about the purpose of the survey. The questionnaire was anonymous, but the name of the city was obligatory. In reporting and analysis of answers, the city name will not be stated.

Through the processing of the survey, results were grouped by categories that may help detect obstacles for the development of the LSDI. Identification of categories was from previous research (Hećimović et al. 2014). Categories in this research are: city budget, city 


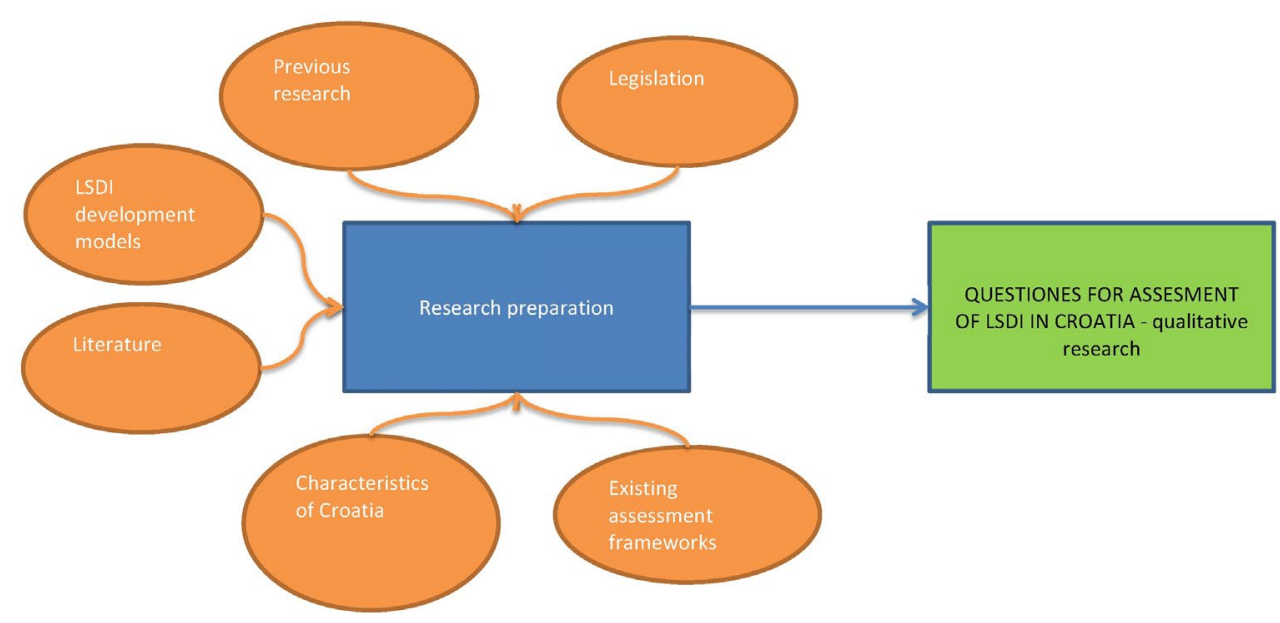

Figure 1. Research methodology.

population and the number of IT experts in the city. City budget and city population, as Croatian LSDI development indicators, had already been assessed in 2011 (Hećimović et al. 2014). That research discovered a relation between the city budget and population and the level of development or existence of LSDI. These categories were used again in the analysis of this questionnaire. Also, in Croatian legislation it is not prescribed that an IT expert should be employed in city government, so the relation between the existence of an IT expert and the existence or level of development of LSDI could be interesting and indicative. This category is grouped by answers to the same question in the questionnaire. Each category was scaled into four groups. Scaling of groups is defined following a proposal of the Ministry of Physical Planning, Construction and Habitation by population of cities (Zimmermann 1999). The budget category was scaled into groups based on category. Also, answers were grouped by whether cities have LSDI or not, as shown in Table 1. This category is grouped by answers to the same question from the questionnaire. This category can be used in the process of identification of indicators. Besides the term LSDI, the questionnaire also used the term GIS because of the lack of knowledge about the term LSDI, as found in Hećimović et al. (2014). The term GIS is more widely used and recognized in Croatia than the term LSDI.

Table 1. Categorization of questionnaire sample by groups.

\begin{tabular}{llr}
\hline Whole sample & & 75 \\
\hline City category by budget & Small budget, 0-30 mil Croatian kunas & 20 \\
& Medium small budget, 30-100 mil Croatian kunas & 36 \\
& Medium large budget, 100-200 mil Croatian kunas & 6 \\
City category by population & Large budget, 200+ mil Croatian kunas & 13 \\
& Small city, 0-10,000 inhabitants & 36 \\
& Medium small city, 10,000-35,000 inhabitants & 27 \\
Do you have IT experts employed in the city / municipal & Medium large city, 35,000-100,000 inhabitants & 8 \\
administration? & Large city, 100,000+ inhabitants & 4 \\
& Yes & 22 \\
& Not full time & 31 \\
Do you have GIS or LSDI for city management? & We use outsourced services & 1 \\
& I do not know & 20 \\
& Yes & 1 \\
& No & 32 \\
\end{tabular}




\section{Questionnaire}

For collecting questionnaire field data, an online survey tool was used: the SoGosurvey service. The questionnaire had 56 questions divided into eight thematic groups. After defining questions, questions were grouped by thematic groups. The thematic groups are:

(1) Thematic group 1. Awareness about SDI and INSPIRE - rates knowledge about SDI (INSPIRE) and legislation.

(2) Thematic group 2. Public spatial data management at local level - rates local governance and usage of public spatial data.

(3) Thematic group 3. Human resource - rates the level of employees' readiness for development and management of LSDI.

(4) Thematic group 4. Hardware and software - rates existing hardware and software for LSDI development and management.

(5) Thematic group 5. Organizational - rates level of strategic thinking in city government to organize, develop, manage and use LSDI.

(6) Thematic group 6. LSDI existence and development - rates existence and development of LSDI.

(7) Thematic group 7. Support and collaboration - rates support, collaboration and cooperation concerning LSDI development.

(8) Commentary - space for comments.

Although qualitative research would give a better picture of the current state of LSDI, there is a reason why quantitative research was chosen. Due to the distribution of cities, quantitative research is cheaper to conduct and less time-consuming. Though a combined method is almost ideal (Tkalec et al. 2010, McDougall 2006), the qualitative part of the research was not conducted. In the analysis, it should be taken into consideration that answers were subjective, because the respondents represented the whole city government, but there is no consensus that his/her opinion is the official opinion of the city government. The first invitation was sent from the Association of Cities to all 127 cities in March 2016. After that, the authors sent the invitation once more to all cities in April 2016. The invitation to complete survey was sent to the department whose domain is related to spatial data, spatial planning and urbanism or if there is no such department, city bodies would choose a representative to answer the questions on the basis of the explanation in the invitation. Once again, an email was sent to cities by the authors in May 2016. After that, the representatives were contacted by telephone to remind the cities about the questionnaire in June and July of 2016. The questionnaire started on 9 March 2016 and finished on 4 July 2016. The representatives of 75 cities responded to the questionnaire. So, the questionnaire response was 59 percent.

\section{Results by thematic groups of questionnaire}

\section{Thematic group 1 - Awareness about SDI and INSPIRE}

The aim of this thematic group is to see if there is a correlation between the existence of LSDI and the level of awareness and knowledge about SDI and INSPIRE. There is still low awareness about SDI and ISNPIRE in Croatia. Such results were similar in research conducted in 2011/12 in Croatia (Hećimović et al. 2014) and Cetl (2007). Also, such results were found 
in a study of Flanders (Belgium), which considered 308 municipalities (Vancauwenberghe et al. 2011). Research conducted in the USA in 2003 (Harvey 2006) revealed familiarity with the term 'NSDI' in 43 percent of respondents. Harvey (2006) carried out qualitative research and found that the answer 'Yes' was weighted with a certain lack of understanding of the term NSDI even though there was a possible answer 'partly', so in the analysis such facts should be taken in consideration.

Only 13 percent of the respondents claim that they know a lot about NSDI and INSPIRE (Table 2). In research conducted in the UK, almost 98 percent of all authorities have at least some understanding of INSPIRE, with over half having a moderate understanding (LGA 2011).

The level of knowledge about other terms related to SDI is significantly higher if such terms are in the Croatian legislation. The question related to the obligation of local government regarding utility cadastres by the Law on State Survey and Real Estate Cadastre (Official Gazette 16/07) reveals that there is a higher level of knowledge about this topic. Fifty-three percent of respondents claimed that the city is familiar with the obligation and taking some steps to fulfil that obligation.

The level of awareness is related to city budget, population, existence of GIS or LSDI and whether an IT expert is employed in city government or not. If the budget or population is higher, then the level of knowledge is higher (Table 2). Also, if there is an IT expert employed in city government or there is GIS or LSDI at a certain level of development, the level of knowledge is higher (Table 2).

Table 2. Influence of awareness about SDI and INSPIRE on level of development of LSDI.

\begin{tabular}{|c|c|c|c|c|}
\hline \multicolumn{2}{|c|}{$\begin{array}{l}\text { Are your familiar with acronyms INSPIRE OR } \\
\text { NSDI? }\end{array}$} & \multirow{2}{*}{$\frac{\text { Sample size }}{75}$} & \multirow{2}{*}{$\begin{array}{c}\begin{array}{c}\text { Don't know a lot } \\
\text { about these terms }\end{array} \\
87 \%\end{array}$} & \multirow{2}{*}{$\begin{array}{c}\begin{array}{c}\text { I know a lot about } \\
\text { these terms }\end{array} \\
13 \%\end{array}$} \\
\hline Whole sample & & & & \\
\hline \multirow[t]{4}{*}{ City category by budget } & $\begin{array}{l}\text { Small budget } 0-30 \text { mil } \\
\text { Croatian kunas }\end{array}$ & 20 & $100 \%$ & $0 \%$ \\
\hline & $\begin{array}{l}\text { Medium small budget } \\
30-100 \text { mil Croatian } \\
\text { kunas }\end{array}$ & 36 & $94 \%$ & $6 \%$ \\
\hline & $\begin{array}{l}\text { Medium large budget } \\
\text { 100-200 mil } \\
\text { Croatian kunas }\end{array}$ & 6 & $67 \%$ & $33 \%$ \\
\hline & $\begin{array}{l}\text { Large budget } 200+ \\
\text { mil Croatian kunas }\end{array}$ & 13 & $54 \%$ & $46 \%$ \\
\hline \multirow[t]{4}{*}{ City category by population } & $\begin{array}{l}\text { Small city } 0-10,000 \\
\text { inhabitants }\end{array}$ & 36 & $97 \%$ & $3 \%$ \\
\hline & $\begin{array}{l}\text { Medium small city } \\
10,000-35,000 \\
\text { inhabitants }\end{array}$ & 27 & $93 \%$ & $7 \%$ \\
\hline & $\begin{array}{l}\text { Medium large city } \\
35,000-100,000 \\
\text { inhabitants }\end{array}$ & 8 & $50 \%$ & $50 \%$ \\
\hline & $\begin{array}{l}\text { Large city } 100,000+ \\
\text { inhabitants }\end{array}$ & 4 & $25 \%$ & $75 \%$ \\
\hline \multirow{5}{*}{$\begin{array}{l}\text { Do you have IT experts } \\
\text { employed in the city / } \\
\text { municipal administration? }\end{array}$} & Yes & 22 & $64 \%$ & $36 \%$ \\
\hline & No & 31 & $97 \%$ & $3 \%$ \\
\hline & Not full time & 1 & $100 \%$ & $0 \%$ \\
\hline & $\begin{array}{l}\text { We use outsourced } \\
\text { services }\end{array}$ & 20 & $100 \%$ & $0 \%$ \\
\hline & I do not know & 1 & $0 \%$ & $100 \%$ \\
\hline \multirow{2}{*}{$\begin{array}{l}\text { Do you have GIS or LSDI for } \\
\text { city management? }\end{array}$} & Yes & 32 & $69 \%$ & $31 \%$ \\
\hline & No & 43 & $100 \%$ & $0 \%$ \\
\hline
\end{tabular}




\section{Thematic group 2 - Spatial data management at the local level}

A crucial part of LSDI is the availability of data and datasets. Collecting and creating data are expensive and very challenging tasks. In this thematic group, the goal is to see which data are most used at the local level and most included in LSDI. Also, it was checked whether there was a correlation between the existence or use of data and the existence of LSDI.

The most-used data from the geoportal of the State Geodetic Administration on a daily basis are digital ortho photos followed by the digital cadastre map and the Croatian basic map at a scale of 1:5000.

Thirty-one percent of the respondents claim that their city publishes data in the Register of Spatial Data Sources of the National Spatial Data Infrastructure (Table 3). The percentage is higher in cities where the city budget is higher, the population is greater, where an IT expert is employed by the city government or where a GIS or LSDI exists at a certain level of development. There is a big percentage of those who answered that they didn't know if their city published data, especially in small cities (Table 3 ).

There is still more than 20 percent of analogue data in use at the local level. There is no correlation between the percentage of analogue data and categories (Table 4). Only 13 percent of cities have procedures for dataset updates. Thirty-eight percent of the respondents claim that they have noticed the duplication of data at the local level and the national level and 44 percent with other data on the local level. Poslončec-Petrić (2010) states that 43 percent of respondents claimed that they noticed the duplication of data. Sixty-eight percent of duplication is noticed in administration (national and local). According to research conducted in 2006 (Cetl 2007), 14 percent of data was in analogue format, while a combination of analogue and digital data was reported in 57 percent of cases.

Table 3. Separation of answers about data publishing by groups.

\begin{tabular}{|c|c|c|c|c|c|}
\hline \multicolumn{2}{|c|}{ Is your city/municipality publishing data as the subject of } & \multirow[b]{2}{*}{ Sample size } & \multirow[b]{2}{*}{ Yes } & \multirow[b]{2}{*}{ No } & \multirow[b]{2}{*}{ I do not know } \\
\hline Spatial Data Infrastructure? & & & & & \\
\hline Whole sample & & 75 & $31 \%$ & $35 \%$ & $35 \%$ \\
\hline \multirow[t]{4}{*}{ City category by budget } & $\begin{array}{l}\text { Small budget } 0-30 \text { mil } \\
\text { Croatian kunas }\end{array}$ & 20 & $10 \%$ & $40 \%$ & $50 \%$ \\
\hline & $\begin{array}{l}\text { Medium small budget 30-100 } \\
\text { mil Croatian kunas }\end{array}$ & 36 & $31 \%$ & $39 \%$ & $31 \%$ \\
\hline & $\begin{array}{l}\text { Medium large budget 100-200 } \\
\text { mil Croatian kunas }\end{array}$ & 6 & $33 \%$ & $50 \%$ & $17 \%$ \\
\hline & $\begin{array}{l}\text { Large budget } 200+\text { mil } \\
\text { Croatian kunas }\end{array}$ & 13 & $62 \%$ & $8 \%$ & $31 \%$ \\
\hline \multirow[t]{4}{*}{ City category by population } & Small city $0-10,000$ inhabitants & 36 & $22 \%$ & $36 \%$ & $42 \%$ \\
\hline & $\begin{array}{l}\text { Medium small city } 10,000- \\
35,000 \text { inhabitants }\end{array}$ & 27 & $30 \%$ & $41 \%$ & $30 \%$ \\
\hline & $\begin{array}{l}\text { Medium large city } 35,000- \\
100,000 \text { inhabitants }\end{array}$ & 8 & $38 \%$ & $25 \%$ & $38 \%$ \\
\hline & $\begin{array}{l}\text { Large city } 100,000+ \\
\text { inhabitants }\end{array}$ & 4 & $100 \%$ & $0 \%$ & $0 \%$ \\
\hline \multirow{5}{*}{$\begin{array}{l}\text { Do you have IT experts } \\
\text { employed in the city / } \\
\text { municipal administration? }\end{array}$} & Yes & 22 & $36 \%$ & $36 \%$ & $27 \%$ \\
\hline & No & 31 & $23 \%$ & $39 \%$ & $39 \%$ \\
\hline & Not full time & 1 & $100 \%$ & $0 \%$ & $0 \%$ \\
\hline & We use outsourced services. & 20 & $30 \%$ & $30 \%$ & $40 \%$ \\
\hline & I do not know & 1 & $100 \%$ & $0 \%$ & $0 \%$ \\
\hline \multirow{2}{*}{$\begin{array}{l}\text { Do you have GIS or LSDI for city } \\
\text { management? }\end{array}$} & Yes & 32 & $47 \%$ & $28 \%$ & $25 \%$ \\
\hline & No & 43 & $19 \%$ & $40 \%$ & $42 \%$ \\
\hline
\end{tabular}


Table 4. Analogue data in use in city government.

\begin{tabular}{|c|c|c|c|c|c|c|}
\hline \multicolumn{2}{|c|}{$\begin{array}{l}\text { Are analogue data used for data storing in the util- } \\
\text { ity cadastre and other infrastructure in your city? }\end{array}$} & \multirow{2}{*}{$\frac{\text { Sample size }}{50}$} & \multirow{2}{*}{$\frac{\text { Yes }}{20 \%}$} & \multirow{2}{*}{$\begin{array}{r}\text { Partly } \\
34 \%\end{array}$} & \multirow{2}{*}{$\begin{array}{l}\text { No } \\
16 \%\end{array}$} & \multirow{2}{*}{$\frac{\text { I do not know }}{30 \%}$} \\
\hline Whole sample & & & & & & \\
\hline City category by budget & Small budget 0-30 mil kn & 13 & $8 \%$ & $38 \%$ & $8 \%$ & $46 \%$ \\
\hline & $\begin{array}{l}\text { Medium small budget } \\
30-100 \text { mil kn }\end{array}$ & 22 & $23 \%$ & $32 \%$ & $23 \%$ & $23 \%$ \\
\hline & $\begin{array}{l}\text { Medium large budget } \\
100-200 \text { mil kn }\end{array}$ & 4 & $50 \%$ & $50 \%$ & $0 \%$ & $0 \%$ \\
\hline & Large budget $200+$ mil kn & 11 & $18 \%$ & $27 \%$ & $18 \%$ & $36 \%$ \\
\hline \multirow[t]{4}{*}{ City category by population } & $\begin{array}{l}\text { Small city } 0-10,000 \\
\text { inhabitants }\end{array}$ & 23 & $9 \%$ & $39 \%$ & $13 \%$ & $39 \%$ \\
\hline & $\begin{array}{l}\text { Medium small city } \\
10,000-35,000 \\
\text { inhabitants }\end{array}$ & 17 & $41 \%$ & $24 \%$ & $18 \%$ & $18 \%$ \\
\hline & $\begin{array}{l}\text { Medium large city } \\
35,000-100,000 \\
\text { inhabitants }\end{array}$ & 7 & $14 \%$ & $43 \%$ & $0 \%$ & $43 \%$ \\
\hline & $\begin{array}{l}\text { Large city } 100,000+ \\
\text { inhabitants }\end{array}$ & 3 & $0 \%$ & $33 \%$ & $67 \%$ & $0 \%$ \\
\hline \multirow{5}{*}{$\begin{array}{l}\text { Do you have IT experts } \\
\text { employed in the city / } \\
\text { municipal } \\
\text { administration? }\end{array}$} & Yes & 16 & $25 \%$ & $38 \%$ & $13 \%$ & $25 \%$ \\
\hline & No & 19 & $21 \%$ & $26 \%$ & $21 \%$ & $32 \%$ \\
\hline & Not full time & 1 & $0 \%$ & $100 \%$ & $0 \%$ & $0 \%$ \\
\hline & $\begin{array}{l}\text { We use outsourced } \\
\text { services }\end{array}$ & 13 & $15 \%$ & $38 \%$ & $8 \%$ & $38 \%$ \\
\hline & I do not know & 1 & $0 \%$ & $0 \%$ & $100 \%$ & $0 \%$ \\
\hline \multirow{2}{*}{$\begin{array}{l}\text { Do you have GIS or LSDI for } \\
\text { city management? }\end{array}$} & Yes & 26 & $27 \%$ & $35 \%$ & $23 \%$ & $15 \%$ \\
\hline & No & 24 & $13 \%$ & $33 \%$ & $8 \%$ & $46 \%$ \\
\hline
\end{tabular}

Among cities that have LSDI, datasets that are complete in one city area are administrative boundaries (in 81 percent of the cities), digital ortho photo (in 78 percent of the cities) and house numbers (in 66 percent of the cities).

Thirty-three percent of city representatives think that they know which working processes in city government can be more efficient if LSDI or GIS is used. If a city has LSDI or GIS, then that percentage is even higher, 56 percent, and for those that have an IT expert this is 68 percent.

Only 16 percent of the cities had made any kind of assessment and 25 percent of respondents say that they have noticed some barriers to LSDI/GIS development. Assessments and noticed barriers are at a higher rate if an IT expert is employed in the city.

For 32 percent of the cities the main LSDI target group is local government, which means that LSDI is used for their own needs. If LSDI already exists in some form, then this percentage is higher: 75 percent. For those cities with an IT expert employed, the percentage is even higher, 87 percent.

\section{Thematic group 3 - Human resources}

Human resources are important in most organizations, and so they are in city government regarding LSDI readiness or development. The goal of this thematic group is to explore how well cities are equipped with experts, level of knowledge and relationship with the development of LSDI. Twenty-nine percent of the cities with an IT expert employed in city government and 35 percent with an employee responsible for hardware and software maintenance do have LSDI or GIS. If LSDI or GIS has any level of development, the percentage of IT experts employed is 50 percent (Table 5). This percentage depends on the budget and 
population as well (Table 5). Similar results were found in previous research (Hećimović et al. 2014). According to the Local Government Association - United Kingdom (LGA) (2011), local authorities in the United Kingdom employ an average of 2.1 full-time and 0.5 part-time staff in their Gl service.

\section{Thematic group 4 - Hardware and software}

The level of readiness for LSDI and development of LSDI depends on hardware and software as well. In this thematic group the goal is to explore how well cities are equipped with hardware and software and to determine whether there is a relationship between the development of LSDI and quality of hardware and software in cities. A local area network (LAN) is used in 59 percent of the cities (Table 6) and 55 percent of the cities use some kind of software for data viewing or editing. Fifteen percent of software used is free and open source software (FOSS) and only eight percent of the representatives claim that they are excellently equipped with IT equipment. The existence of LAN is related to the amount of budget, the population number and the existence of LSDI or whether an IT expert is employed in the city (Table 6). According to research conducted in 2012 (Blagonić 2012), the percentage of free software in current LSDI projects in the Republic of Croatia was 18 percent, while in the EU it is 54 percent, as opposed to the USA where commercial software is used exclusively. According to the LGA (2011), in the UK proprietary software is used by 58 percent of authorities for their web service technology and 11 percent use open source, while just fewer than 10 percent use in-house solutions.

Table 5. Separation of relationship between existence of LSDI and employed IT experts in city administration.

\begin{tabular}{|c|c|c|c|c|c|}
\hline \multicolumn{2}{|c|}{$\begin{array}{l}\text { Do you have IT experts employed in the city } \\
\text { administration? }\end{array}$} & \multirow{2}{*}{$\frac{\text { Sample size }}{75}$} & \multirow{2}{*}{$\begin{array}{c}\text { Yes, full time } \\
29 \%\end{array}$} & \multirow{2}{*}{$\frac{\text { Not full time }}{69 \%}$} & \multirow{2}{*}{$\frac{\text { I do not know }}{1 \%}$} \\
\hline Whole sample & & & & & \\
\hline City category by budget & $\begin{array}{l}\text { Small budget 0-30 } \\
\text { mil Croatian kunas }\end{array}$ & 20 & $5 \%$ & $95 \%$ & \\
\hline & $\begin{array}{l}\text { Medium small budget } \\
30-100 \text { mil Croatian } \\
\text { kunas }\end{array}$ & 36 & $14 \%$ & $86 \%$ & \\
\hline & $\begin{array}{l}\text { Medium large budget } \\
\text { 100-200 mil } \\
\text { Croatian kunas }\end{array}$ & 6 & $83 \%$ & $17 \%$ & \\
\hline & $\begin{array}{l}\text { Large budget } 200+ \\
\text { mil Croatian kunas }\end{array}$ & 13 & $85 \%$ & $8 \%$ & $8 \%$ \\
\hline \multirow[t]{4}{*}{$\begin{array}{l}\text { City category by } \\
\text { population }\end{array}$} & $\begin{array}{l}\text { Small city 0-10,000 } \\
\text { inhabitants }\end{array}$ & 36 & $3 \%$ & $97 \%$ & \\
\hline & $\begin{array}{l}\text { Medium small city } \\
\text { 10,000-35,000 } \\
\text { inhabitants }\end{array}$ & 27 & $37 \%$ & $63 \%$ & \\
\hline & $\begin{array}{l}\text { Medium large city } \\
35,000-100,000 \\
\text { inhabitants }\end{array}$ & 8 & $100 \%$ & $0 \%$ & \\
\hline & $\begin{array}{l}\text { Large city } 100,000+ \\
\text { inhabitants }\end{array}$ & 4 & $75 \%$ & $0 \%$ & $25 \%$ \\
\hline \multirow{2}{*}{$\begin{array}{l}\text { Do you have GIS or LSDI } \\
\text { for city management? }\end{array}$} & Yes & 32 & $50 \%$ & $47 \%$ & $3 \%$ \\
\hline & No & 43 & $14 \%$ & $86 \%$ & \\
\hline
\end{tabular}


Table 6. Existence of LAN in cities separated by groups.

\begin{tabular}{|c|c|c|c|c|c|}
\hline \multicolumn{2}{|c|}{ Do your use LAN in city management? } & \multirow{2}{*}{$\frac{\text { Sample size }}{75}$} & \multirow{2}{*}{$\begin{array}{l}\text { Yes } \\
59 \%\end{array}$} & \multirow{2}{*}{$\frac{\text { No }}{21 \%}$} & \multirow{2}{*}{$\frac{\text { I do not know }}{20 \%}$} \\
\hline Whole sample & & & & & \\
\hline \multirow[t]{4}{*}{ City category by budget } & $\begin{array}{l}\text { Small budget } 0-30 \text { mil } \\
\text { Croatian kunas }\end{array}$ & 20 & $45 \%$ & $40 \%$ & $15 \%$ \\
\hline & $\begin{array}{l}\text { Medium small budget 30-100 } \\
\text { mil Croatian kunas }\end{array}$ & 36 & $56 \%$ & $22 \%$ & $22 \%$ \\
\hline & $\begin{array}{l}\text { Medium large budget 100-200 } \\
\text { mil Croatian kunas. }\end{array}$ & 6 & $67 \%$ & $0 \%$ & $33 \%$ \\
\hline & $\begin{array}{l}\text { Large budget } 200+\text { mil } \\
\text { Croatian kunas }\end{array}$ & 13 & $85 \%$ & $0 \%$ & $15 \%$ \\
\hline \multirow[t]{4}{*}{ City category by population } & $\begin{array}{l}\text { Small city } 0-10,000 \text { inhabit- } \\
\text { ants }\end{array}$ & 36 & $56 \%$ & $25 \%$ & $19 \%$ \\
\hline & $\begin{array}{l}\text { Medium small city } 10,000- \\
35,000 \text { inhabitants }\end{array}$ & 27 & $56 \%$ & $26 \%$ & $19 \%$ \\
\hline & $\begin{array}{l}\text { Medium large city } 35,000- \\
100,000 \text { inhabitants }\end{array}$ & 8 & $75 \%$ & $0 \%$ & $25 \%$ \\
\hline & $\begin{array}{l}\text { Large city } 100,000+ \\
\text { inhabitants }\end{array}$ & 4 & $75 \%$ & $0 \%$ & $25 \%$ \\
\hline \multirow{5}{*}{$\begin{array}{l}\text { Do you have IT experts } \\
\text { employed in the city / } \\
\text { municipal administration? }\end{array}$} & Yes & 22 & $77 \%$ & $0 \%$ & $23 \%$ \\
\hline & No & 31 & $35 \%$ & $42 \%$ & $23 \%$ \\
\hline & Not full time & 1 & $100 \%$ & & \\
\hline & We use outsourced services & 20 & $75 \%$ & $15 \%$ & $10 \%$ \\
\hline & I do not know & 1 & $0 \%$ & $0 \%$ & $100 \%$ \\
\hline \multirow{2}{*}{$\begin{array}{l}\text { Do you have GIS or LSDI for city } \\
\text { management? }\end{array}$} & Yes & 32 & $78 \%$ & $9 \%$ & $13 \%$ \\
\hline & No & 43 & $44 \%$ & $30 \%$ & $26 \%$ \\
\hline
\end{tabular}

\section{Thematic group 5 - Organization}

Organizational issues are included in most SDI assessment studies. The goal of this thematic group is to identify how cities are organized and how organizational issues are related to the development of LSDI. Only 16 percent of the cities have formally documented their strategy about LSDI/GIS (Table 7). Only eight percent of the respondents claim that their strategy includes any kind of PR (public relations) related to LSDI/GIS. The same percentage have some kind of PR related to LSDI/GIS. Just three percent of the respondents have a defined vision and timeframe for LSDI/GIS development or management. Six percent of the respondents' organizations have already defined objectives for LSDI/GIS. Defined organizational structure for LSDI/GIS development and management is present in 19 percent of the cities and almost all LSDI/GIS are financed by local government. The percentage of documented strategy about LSDI/GIS is related to the budget, the population, the existence of LSDI and whether an IT expert is employed by the city. If the budget or population is higher or there is LSDI/GIS or an IT expert in the city, then the percentage of cities that have a strategy is higher (Table 7).

\section{Thematic group 6 - LSDI existence and development}

Forty-three percent of the respondents claim that their city does have GIS or LSDI for city management (Table 8). If a city has a higher budget, a bigger population or an IT expert employed in the city, then the existence of LSDI or GIS is more likely (Table 8). At the beginning of this century the development of LSDI or GIS had started in more cities, although some cities had started using GIS or LSDI for management earlier. According to research (Blagonić 2012) conducted over existing geoportals accessible to the public, LSDI was 
Table 7. Percentage of strategies in cities separated by groups.

\begin{tabular}{|c|c|c|c|c|c|}
\hline \multicolumn{2}{|c|}{$\begin{array}{l}\text { Does your city have a strategy for LSDI / GIS development and/ } \\
\text { or management? }\end{array}$} & \multirow{2}{*}{$\frac{\text { Sample size }}{20}$} & \multirow{2}{*}{ Yes } & \multirow{2}{*}{ No } & \multirow{2}{*}{$\frac{\text { Do not know }}{20 \%}$} \\
\hline City category by budget & $\begin{array}{l}\text { Small budget 0-30 mil Croatian } \\
\text { kunas }\end{array}$ & & & & \\
\hline & $\begin{array}{l}\text { Medium small budget 30-100 } \\
\text { mil Croatian kunas }\end{array}$ & 36 & $8 \%$ & $58 \%$ & $33 \%$ \\
\hline & $\begin{array}{l}\text { Medium large budget 100-200 } \\
\text { mil Croatian kunas }\end{array}$ & 6 & $17 \%$ & $33 \%$ & $50 \%$ \\
\hline & $\begin{array}{l}\text { Large budget 200- mil Croatian } \\
\text { kunas }\end{array}$ & 13 & $54 \%$ & $15 \%$ & $31 \%$ \\
\hline \multirow[t]{4}{*}{ City category by population } & Small city $0-10,000$ inhabitants & 36 & $3 \%$ & $61 \%$ & $36 \%$ \\
\hline & $\begin{array}{l}\text { Medium small city } 10,000- \\
35,000 \text { inhabitants }\end{array}$ & 27 & $19 \%$ & $59 \%$ & $22 \%$ \\
\hline & $\begin{array}{l}\text { Medium large city } 35,000- \\
100,000 \text { inhabitants }\end{array}$ & 8 & $38 \%$ & $25 \%$ & $38 \%$ \\
\hline & Large city $100,000+$ inhabitants & 4 & $75 \%$ & & $25 \%$ \\
\hline \multirow{5}{*}{$\begin{array}{l}\text { Do you have IT experts employed } \\
\text { in the city / municipal } \\
\text { administration? }\end{array}$} & Yes & 22 & $32 \%$ & $36 \%$ & $32 \%$ \\
\hline & No & 31 & & $71 \%$ & $29 \%$ \\
\hline & Not full time & 1 & & & $100 \%$ \\
\hline & We use outsourced services & 20 & $25 \%$ & $50 \%$ & $25 \%$ \\
\hline & I do not know & 1 & & & $100 \%$ \\
\hline \multirow{2}{*}{$\begin{array}{l}\text { Do you have GIS or LSDI for city } \\
\text { management? }\end{array}$} & Yes & 32 & $34 \%$ & $28 \%$ & $38 \%$ \\
\hline & No & 43 & $2 \%$ & $72 \%$ & $26 \%$ \\
\hline
\end{tabular}

Table 8. Existence of LSDI or GIS in cities separated by groups.

\begin{tabular}{|c|c|c|c|c|}
\hline \multicolumn{2}{|c|}{ Do you have GIS or LSDI for city management? } & \multirow{2}{*}{$\frac{\text { Sample size }}{20}$} & \multirow{2}{*}{$\begin{array}{c}\text { Yes } \\
10 \%\end{array}$} & \multirow{2}{*}{$\begin{array}{c}\text { No } \\
90 \%\end{array}$} \\
\hline City category by budget & Small budget 0-30 mil Croatian kunas. & & & \\
\hline & $\begin{array}{l}\text { Medium small budget 30-100 mil } \\
\text { Croatian kunas. }\end{array}$ & 36 & $44 \%$ & $56 \%$ \\
\hline & $\begin{array}{l}\text { Medium large budget } 100-200 \mathrm{mil} \\
\text { Croatian kunas. }\end{array}$ & 6 & $50 \%$ & $50 \%$ \\
\hline & Large budget 200+ mil Croatian kunas. & 13 & $85 \%$ & $15 \%$ \\
\hline \multirow[t]{4}{*}{ City category by population } & Small city $0-10,000$ inhabitants. & 36 & $28 \%$ & $72 \%$ \\
\hline & $\begin{array}{l}\text { Medium small city } 10,000-35,000 \\
\text { inhabitants. }\end{array}$ & 27 & $41 \%$ & $59 \%$ \\
\hline & $\begin{array}{l}\text { Medium large city } 35,000-100,000 \\
\text { inhabitants. }\end{array}$ & 8 & $88 \%$ & $13 \%$ \\
\hline & Large city $100,000+$ inhabitants. & 4 & $100 \%$ & $0 \%$ \\
\hline \multirow{5}{*}{$\begin{array}{l}\text { Do you have IT experts employed in the } \\
\text { city / municipal administration? }\end{array}$} & Yes. & 22 & $73 \%$ & $27 \%$ \\
\hline & No. & 31 & $23 \%$ & $77 \%$ \\
\hline & Not full time. & 1 & $0 \%$ & $100 \%$ \\
\hline & We use outsourced services. & 20 & $40 \%$ & $60 \%$ \\
\hline & I do not know. & 1 & $100 \%$ & $0 \%$ \\
\hline
\end{tabular}

established in 13 percent of the cities, which is lower than our results. Such a difference is possible due to the respondents' lack of understanding of terms related to GIS or LSDI or because LSDI is not accessible to the public, considering research conducted over existing geoportals. Also during a period of 5 years, LSDI or GIS has been developed in some cities. In research (Hećimović et al. 2014) conducted in 2011/2012, 37 percent of the cities claimed that their city had LSDI or GIS.

\section{Thematic group 7 - Support and collaboration}

Support and collaboration are recognized as two of the key indicators of successful (L)SDls. The goal of this thematic group is to explore whether there is support and collaboration 
with various subjects (institutions, individual experts, private firms, political structures, etc.) and between which subjects there is collaboration. Another goal was to see the relationship between the existence of support and collaboration and the existence of LSDI/GIS. Regarding political support, 35 percent of the respondents claim that they have support from politicians at the local level and only seven percent of the respondents claim that they have support at the national level. The second biggest source of support is from individual SDI experts (24 percent) and from some institutions at the local level (21 percent). According to a study conducted in the USA (Budić 1993), at the beginning of the development of LSDIs (1993) the most functional GIS had a strong political support.

Almost 70 percent of initiatives for LSDI development are from local government. Only nine percent of LSDIs or GISs were not initiated from the local level (government, institution, individual, etc.).

Among those that have LSDI, 69 percent are ready to share their 'know-how' with other cities or municipalities. There is no formalized network at all. Twenty-eight percent of the cities with LSDI or GIS claim that they are in some kind of network, but this network is not formalized. The most common method for networking is occasional meetings (19 percent) in non-formalized networking.

Ninety-three percent of the respondents think that some institution on the national level should inform them about the terms mentioned (INSPIRE, SDI), their meanings and difficulties in city management. Ninety-five percent of the respondents think that a web community (tutorials, best cases, video meetings, etc.) with representatives of all cities and various experts could improve knowledge, development and LSDI quality (Table 9). Forty-eight percent of city representatives think that their city would be ready to cooperate with other cities for LSDI development and 49 percent 'don't know' the answer to that question. This decision should be decided by a mayor or a city council, so this high percentage (49 percent don't know) is likely to be related to that fact. Similar results could be found in previous research (Hećimović et al. 2014). In the United Kingdom (LGA 2011), a lack of resources is the most commonly cited barrier to INSPIRE compliance (81 percent). This is followed by a lack of understanding of the implications of INSPIRE (61 percent). In addition, most respondents would like to have specific local authority guidance (88 percent). Finally, according to the LGA (2011), there is an overwhelming request for regional events on INSPIRE, possibly as an information session as part of PSMA (Public Sector Mapping Agreement) or other events or direct support to local authorities to implement INSPIRE.

Forty-seven percent of the respondents from local administrations have never been contacted by anyone about LSDI/GIS status, development or management. Most contacts to city administration came from private firms from other cities (35 percent), followed by individual SDI experts and national institutions (11 percent). The reason why contacts from private firms are most frequent could be the fact that most cities don't have private firms that do business with spatial data. Such firms are almost always located in bigger or the biggest cities. Almost half, 48 percent, of all cities have never contacted anyone about LSDI/ GIS status, development or management. Most contacts from the city were to private firms from other cities (31 percent), individual SDI experts (20 percent) and national institutions (13 percent).

Twenty-one percent of the cities have some formal cooperation at the local level and 17 percent have formal cooperation at the national level. Informal cooperation is higher at the local level (32 percent) than at the national level (12 percent). 
Table 9. Need for support and collaboration from web multidisciplinary community separated by groups.

\begin{tabular}{|c|c|c|c|c|}
\hline \multicolumn{2}{|c|}{$\begin{array}{l}\text { Do your think that web community (tutorials, best cases, video meetings } \\
\text { etc.) with representative of all cities and various expert representatives could } \\
\text { improve knowledge, development and LSDI quality? }\end{array}$} & \multirow{2}{*}{$\frac{\text { Sample size }}{20}$} & \multirow{2}{*}{$\begin{array}{l}\text { Yes } \\
95 \%\end{array}$} & \multirow{2}{*}{ No } \\
\hline City category by budget & Small budget 0-30 mil Croatian kunas & & & \\
\hline & $\begin{array}{l}\text { Medium small budget 30-100 mil } \\
\text { Croatian kunas }\end{array}$ & 36 & $94 \%$ & $6 \%$ \\
\hline & $\begin{array}{l}\text { Medium large budget 100-200 mil } \\
\text { Croatian kunas }\end{array}$ & 6 & $100 \%$ & $0 \%$ \\
\hline & Large budget $200+$ mil Croatian kunas & 13 & $92 \%$ & $8 \%$ \\
\hline \multirow[t]{4}{*}{ City category by population } & Small city $0-10,000$ inhabitants & 36 & $97 \%$ & $3 \%$ \\
\hline & $\begin{array}{l}\text { Medium small city 10,000-35,000 } \\
\text { inhabitants }\end{array}$ & 27 & $89 \%$ & $11 \%$ \\
\hline & $\begin{array}{l}\text { Medium large city } 35,000-100,000 \\
\text { inhabitants }\end{array}$ & 8 & $100 \%$ & $0 \%$ \\
\hline & Large city $100,000+$ inhabitants & 4 & $100 \%$ & $0 \%$ \\
\hline \multirow{5}{*}{$\begin{array}{l}\text { Do you have IT experts employed in the } \\
\text { city / municipal administration? }\end{array}$} & Yes & 22 & $100 \%$ & $0 \%$ \\
\hline & No & 31 & $90 \%$ & $10 \%$ \\
\hline & Not full time & 1 & $100 \%$ & $0 \%$ \\
\hline & We use outsourced services & 20 & $95 \%$ & $5 \%$ \\
\hline & I do not know & 1 & $100 \%$ & $0 \%$ \\
\hline \multirow{2}{*}{$\begin{array}{l}\text { Do you have GIS or LSDI for city } \\
\text { management? }\end{array}$} & Yes & 32 & $97 \%$ & $3 \%$ \\
\hline & No & 43 & $93 \%$ & $7 \%$ \\
\hline
\end{tabular}

There is more support for LSDI/GIS development at the local level if a city has LSDI/GIS or if there is an IT expert employed by the city. Interaction between the city and various stakeholders is more intensive if there is LSDI or GIS in the city or if the city has an IT expert employed. This research reveals that private firms from another city or municipality often contact the city about LSDI if there is LSDI (44 percent) or if an IT expert is employed in the city (55 percent). In the whole sample that percentage is lower (35 percent). A similar conclusion can be made about formal cooperation at the local or national level. It is higher if there is LSDI or GIS and even higher if an IT expert is employed in the city. For cooperation with the national level, it is clear that is related to the budget or population of the city.

\section{Comments in questionnaire}

Representatives of cities have recognized various barriers to the development of LSDI like: lack of human resources, harmonization of data, interoperability, organizational issues, financial problems, lack of support from the national level, strategic problems, and lack of metadata, inaccurate data and lack of knowledge in the management of local government. Spatial data that are mostly mentioned are data from utility registers from a company in the ownership of local government or a private company. There is a strong 'voice' about the need for support from the national level.

\section{Interpretation of the results}

Besides primary data from the questionnaire, secondary data were also used for interpretation. Secondary data about population were found at the Croatian Bureau of Statistics (URL3 2001) (from a list of the population from 2001 and 2012), while city budgets from 2016 were found on the official Internet pages of the cities. 
The level of knowledge and activities on LSDI at the local level appears to depend on legislation. Datasets that are included the most in LSDIs are administrative boundaries and house numbers and those datasets are prescribed by law. It is obvious that if there is legislation related to LSDI and local government, the knowledge about LSDI is at a higher level. This could be related to political, institutional, academic, market and individual activities generated by legislation. It appears that most cities react better if there is a formal impulse from some institution at the national level. This is in correlation with research by Budić (1993) and McDougall et al. (2005).

The percentage of LSDIs in Croatia is rising. In five years, from 2011 to 2016, there were six percent more LSDIs in Croatia. They are mostly developed for the needs of city government. City government does not recognize PR for promoting LSDI. There is no horizontal or vertical interoperability between LSDI subjects or it is weak. A low percentage of formal and informal collaboration between various stakeholders goes in support of this statement. It could be said that the potential of LSDI is not as exploited as it could be or it is not even recognized at all. There is most likely no drive for efficiency and effectiveness in most cities if we take a look at assessments made about LSDI efficiency. Additionally, there is a low percentage of strategic approaches to organize and develop LSDI. Most initiatives for developing LSDI are from the local level and depend on political support. It could be said that local leaders are those who have initiated most current LSDIs through political support at the local level.

There is a will for networking and sharing of knowledge but it is most likely that a 'leader' (most likely an institution on the national level) is still missing in the 'real world'. Cities are looking for public rather than private institutions at the national level that should inform them about SDI development. Almost every city would like a web community (tutorials, best cases, video meetings, etc.) with representatives of all cities and a multidisciplinary team of experts which should improve knowledge, development and LSDI quality. As in the UK (LGA, 2011), cities in Croatia would definitely like guidance for LSDI development and management and INSPIRE implementation from some institution at the national level.

Lack of finance and support, especially political and institutional, from the national level is one of the main barriers to LSDI development.

Cities with higher budgets have a higher percentage of developed LSDI. Cities with developed LSDI have a higher percentage of employed IT experts. Finally, budget, population and employed IT experts are correlated with the existence and quality of LSDI. Similar conclusions could be found in Hećimović et al. (2014).

If there is more budget or a larger population or IT experts employed in the city, an increase of awareness, spatial data management, human resources, hardware and software, organizational capabilities and LSDI existence are more likely to be developed at a higher-quality level.

A deeper analysis should be made to better recognize indicators and this will be followed up further on in this research. It would be interesting to find whether there are some indicators that apply for all countries or whether they depend on certain conditions. Developing LSDI in any local government could be easier if it is correlated with an existing one over recognized unique indicators. Also new LSDIs would be more feasible.

\section{Conclusions}

LSDI in the Republic of Croatia is developed mostly on the initiative of local governments. LSDI has mostly been developed by inertia in direction considering the practical needs of 
each city. Almost all cities stated that they need guidance for the development of organized LSDI and that guidance is necessary to implement INSPIRE by 2020. To solve the gap between the current situation and the situation aimed at for 2020, more intensive communication and cooperation would help. Communication and cooperation should be initiated through a competent institution and supported at the national level to improve the dynamics of development and the improvement of LSDI. Local governments need research, studies and workshops to see what LSDI can do for the management of their cities. Development guided from the national level should take into consideration the financial and other possibilities of each city. It is possible that more than one LSDI development model is needed depending on the potential of each city. It is also necessary to solve the problem of data harmonization and interoperability.

Regarding the situation of LSDI in Croatia, LSDI in general has problems especially with political guidance, institutional leadership, metadata, datasets, individual leadership, cost recovery and private funding and spatially related (open source) software. Problems are noticeable and significant in all factors related to SDI readiness: organizational, informational, human resources, technological and financial resources. Of course, there is a difference between readiness in smaller and bigger cities. Bigger cities (by budget and by population) are much more ready than small cities.

Despite the situation with LSDI in Croatia, there was progress of six percent in the number of LSDI during a period of 5 years. In previous research (Hećimović et al. 2014) there were 27 cities with GIS or LSDI and in this research there are 32 cities with GIS or LSDI. These data are comparable since the response rates in the research from 2011 (57 percent) and this one (59 percent) are similar.

The performance of LSDI in Croatia in general is very low. The main problems for performance are in policy, management and operational level. From this research it is obvious that cities with more budget and larger populations have a better-developed policy, management and operational level. Also, there is practically no assessment of performance (review of objectives and strategies, performance and reliability of system) and user satisfaction.

Budget, the population of the city and the existence of an IT expert in city government influence the development and quality of LSDI. Still, further research and analysis are needed to recognize other indicators for LSDI development. Such indicators could be related to the economy of the state, capital infrastructure projects, the level of integration with other countries, etc. Finally, for better understanding of the state of SDI at the local level, qualitative research should be carried out to better understand the needs and possibilities of cities. That research should give answers on some questions such as: which working processes are the most common in the management of cities or firms owned by city governments and could be improved by implementation of LSDI? This should improve the quality of guidance, which is really needed. A pilot project in one city could help in better understanding the situation at the local level as well as the possibilities of vertical and horizontal cooperation between cities and the national level of SDI. Periodically a questionnaire about LSDI in Croatia should improve and promote LSDI. Since the economic power of local governments in Croatia is weak, research should reveal the best business model for LSDI development.

\section{Disclosure statement}

No potential conflict of interest was reported by the authors. 


\section{ORCID}

Joep Crompvoets (D) http://orcid.org/0000-0003-1077-597X

\section{References}

Blagonić, B., 2012. Katastar vodova u lokalnoj infrastrukturi prostornih podataka, doktorska disertacija. Geodetski fakultet, Zagreb: Sveučilište u Zagrebu.

Budić, Z.D., 1993. GIS Use Among South-eastern Local Governments. Urisa Journal, 5 (1), 4-17.

Cetl, V., 2007. Analiza poboljšanja infrastrukture prostornih podataka, doktorska disertacija. Geodetski fakultet, Zagreb: Sveučilište u Zagrebu.

Christiansen, J.S., Hvingel, L., and Hansen, H.S., 2011. Assessing SDI readiness of the Danish municipalities - presentation. Edinburgh: INSPIRE conference.

Crompvoets, J., et al., 2008. A multi - view framework to assess spatial data infrastructures, Space for Geo-Information (RGI). Wageningen: University for SDIs and Land Administration, Department of Geomatics, The University of Melbourne, Australia

Delgado Fernandez, T., Delgado Fernandez, M. and Espin Andrade, R., 2008. The Spatial Data Infrastructure Readiness model and its worldwide application, A multi - view framework to assess spatial data infrastructures, Space for Geo-Information (RGI). Wageningen: University for SDIs and Land Administration, Department of Geomatics, The University of Melbourne, Australia.

EEA (European Environment Agency), 2014. Mid-term evaluation report on INSPIRE implementation, Joint EEA-JRC report, EEA Technical report No 17/2014, Report EUR 91574 EN

Giff, G., 2008. A framework for designing performance indicators for spatial data infrastructure assessment, a multi - view framework to assess spatial data infrastructures, Space for Geo-Information (RGI). Wageningen: University for SDIs and Land Administration, Department of Geomatics, The University of Melbourne, Australia.

Giff, G. and Crompvoets, J., 2008. Performance Indicators a tool to Support Spatial Data Infrastructure assessment. Computers, Environment and Urban Systems, 32 (5), 365-376, doi:10.1016/j. compenvurbsys.2008.08.001.

Grus, L., Crompvoets, J. and Bregt, A.K., 2008. Theoretcal introduction to the multi-view framework to assess SDIs, A multi - view framework to assess spatial data infrastructures, space for Geo-Information $(R G I)$. Wageningen: University for SDIs and Land Administration, Department of Geomatics, The University of Melbourne, Australia.

Harvey, F., 2006. Local SDI practice in US - Expactations and reality, prezentation. Italija: Ispra.

Harvey, F. and Tulloch, D., 2003. Building the NSDI at the Base: Establishing best sharing and coordination practices among local governments. Available from: https://doi.org/doi:10.7282/T35D8PX6.

Hećimović, Ž., Marasović, S. and Crompvoets, J., 2014. Development of local spatial data infrastructure in Croatia. Journal of Spatial Science, Spatial Sciences Institute, 52, 221-234, ISSN 1449-8596

Jacoby, S., et al., 2002. Developing a common spatial data infrastructure between state and local government - an Australian case study. International Journal of Geographical Information Science, $16(4), 305-322$.

Local Government Association - United Kingdom (LGA), 2011. Local government INSPIRE survey 2011. UK: Local Government Association.

McDougall, K., 2006. A local-state government spatial data sharing partnership model to facilitate SDI development, the university of Melbourne. Australia: Melobourne.

McDougall, K., Rajabifard, A., and Wiliamson, I., 2002. From Little things big things grow: building the SDI from local government up. Joint AURISA and Institute of Surveyors Conference, Adelaide

McDougall, K., Rajabifard, A., and Wiliamson, I., 2005. What will motivate local governments to share spatial information? Proceedings of SSC 2005 Spatial Intelligence, Innovation and Praxis: The national biennial Conference of the Spatial Sciences Institute, Melbourne

McDougall, K., Rajabifard, A., and Wiliamson, I., 2009. Local Government and SDI - Understanding their Capacity to Share Data, SDI Convergence. Research, Emerging trends, and Critical Assessment, Nederland's Commissie voor Geodesie Netherlands Geodetic Commission 48, The Netherlands 
Poslončec - Petrić, V., 2010. Disertacija prostornih podataka za potrebe službene kartografije. PhD, University of Zagreb, Faculty of Geodesy.

Rajabifard, A., 2007. A Spatial Data Infrastructure for a Spatially Enabled Government and Society, A Multi - View Framework to Assess Spatial Data Infrastructures, Space for Geo-Information (RGI). Wageningen: University for SDIs and Land Administration, Department of Geomatics, The University of Melbourne, Australia.

Rix, J., et al., 2011. Methodology to describe, analyse and assess Sub-national SDIs: survey, experiences and lessons learnt. International Journal of Spatial Data Infrastructures Research, 6, 23-52, USA.

Steudler, D., Rajabifard, A., and Wiliamson, I., 2008. Evaluation and performance indicators to assess spatial data infrastructure initiatives, a multi - view framework to assess spatial data infrastructures, space for geo-information (RGI). Wageningen: University for SDIs and Land Administration, Department of Geomatics, The University of Melbourne, Australia.

Tkalec Verčić, A., Sinčić Ćorić, D., and Pološki Vokić, N., 2010. Priručnik za metodologiju istraživačkog rada-kako osmisliti, provesti l opisati znanstveno I stručno istraživanje. Zagreb: M.E.P. d.o.o., Hrvatska.

Tulloch, D.L. and Harvey, F., 2007. When data sharing Becomes Institutionalized: Best Practices in Local Government Geographic Information Relationships. URISA Journal, 19 (2), 51-59.

Vancauwenberghe, G., et al., 2011. Een Gemeentebrede Kijk op GIS, Kwantitatieve Analyse van het Gebruik van Geo-informatie in de Vlaamse Gemeenten [A city wide look at GIS, quantitative analysis of the use of geoinformation in the Flemish municipalities]. Leuven: SPATIALIST Association of Flemish Cities and Municipalities.

Vandenbroucke, D., Janssen, K., and van Orshoven, J., 2008. INSPIRE State of Play: generic approach to assess the status of NSDIs, a multi - view framework to assess spatial data infrastructures, Space for Geo-Information (RGI). Wageningen: University for SDIs and Land Administration, Department of Geomatics, The University of Melbourne, Australia.

Vandenbroucke, D., et al., 2013. A methodology to assess the performance of spatial data infrastructures in the context of work processes. Computers, Enviroments and Urban Systems, 38, 58-66.

Vico, F. et al., 2010. SDI Self-Assessment Framework, eSDI-Net+European Network on Geographic Information Enrichment and Reuse, eContentplus programme. In: European SDI Best Practice Awards 2009 Learning from Best Practices, International Conference, 26th and 27th November 2009 Turin, Italy.

Zimmermann, R., 1999. Prijedlog određenja srednjih gradova u Hrvatskoj, UDK: 711. 43(497. 5). Zagreb: Ministarstvo prostornog uređenja, graditeljt1va i stanovanja.

\section{URL}

URL 3: Croatian Bureau of Statistics, 2001. http://www.dzs.hr/Hrv/censuses/Census2001/Popis/Graphs/ gusposto_hrvbody.html (31.05.2012.) 